\title{
First example of autooxidation of methyl and cyclohexano groups attached to the pyrrole ring: stabilization effect of phenyldiazenyl substituents
}

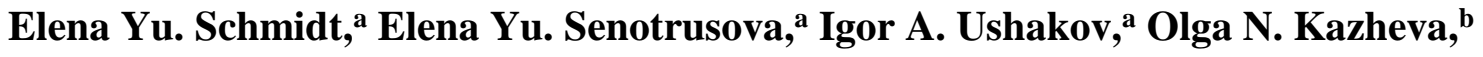 \\ Oleg A. Dyachenko, ${ }^{b}$ Grigorii G. Alexandrov, ${ }^{c}$ Andrei V. Ivanov ${ }^{a}$, Albina I. Mikhaleva, ${ }^{\text {a }}$ \\ and Boris A. Trofimov ${ }^{a^{*}}$ \\ ${ }^{a}$ A. E. Favorsky Irkutsk Institute of Chemistry, Siberian Branch of the Russian Academy of \\ Sciences, 1 Favorsky Str., 664033 Irkutsk, Russian Federation \\ ${ }^{b}$ Institute of Problems of Chemical Physics, Russian Academy of Sciences, 1 Academician N. N. \\ Semenov Str., 142432 Chernogolovka, Russian Federation \\ ${ }^{c}$ N. S. Kurnakov Institute of General and Inorganic Chemistry, Russian Academy of Sciences, \\ 119991 Moscow, Russian Federation \\ E-mail: boris_trofimov@irioch.irk.ru
}

DOI: http://dx.doi.org/10.3998/ark.5550190.0011.230

\begin{abstract}
Methyl substituted 2-phenyldiazenyl- $N$-vinylpyrroles when refluxed in toluene in the airflow are unexpectedly oxidized at their methyl substituents retaining the pyrrole and $N$-vinyl moieties intact. The major products of the autooxidation are hydroxyalkyl derivatives (yield up to 60\%), the corresponding aldehydes being formed in minor quantities (yield up to $21 \%$ ). This nontypical oxidation of substituted pyrroles opens a conceptually novel approach to functionalization of phenyldiazenylpyrrole dyes.
\end{abstract}

Keywords: 2-phenyldiazenyl- $N$-vinylpyrroles, 2-hydroxymethyl- $N$-vinylpyrroles, $N$-vinylpyrrole-2-carbaldehydes, autooxidation

\section{Introduction}

Pyrroles are known to be easily oxidized on air with the participation of the pyrrole ring. ${ }^{1}$ Also is known that the double bonds adjacent to heteroatoms undergo ready autooxidation as well. ${ }^{2}$

Recently, we have synthesized a new family of reactive phenyldiazenylpyrrole dyes by direct azo-coupling of $\mathrm{N}$-vinylpyrroles with aryldiazonium salts. ${ }^{3}$ Further functionalization of these dyes will increase their potential application. For this purpose, a better understanding of their reactivity towards oxidizers appears to be also important, especially having in mind that these functionalized pyrroles attract growing attention. ${ }^{4}$ 


\section{Results and Discussion}

Here we report the first examples of a peculiar autooxidation of substituted 2-phenyldiazenyl- $N$ vinylpyrroles 1a-c and 2-diazenyl- $N$-vinyl-4,5,6,7-tetrahydroindole $1 \mathbf{d}$ which unexpectedly proceeds selectively at 5-methyl substituents and at 7-position of cyclohexane moiety with preserving the pyrrole ring, $N$-vinyl and azo groups (Scheme 1). The isolated yields of the hydroxy derivatives $\mathbf{2 a - d}$ range 18-60\%. In the case of pyrroles $\mathbf{1 b}, \mathbf{c}$, the minor products of the oxidation are the corresponding aldehydes $\mathbf{3 b}, \mathbf{c}$, the yields of which not exceeding $21 \%$.

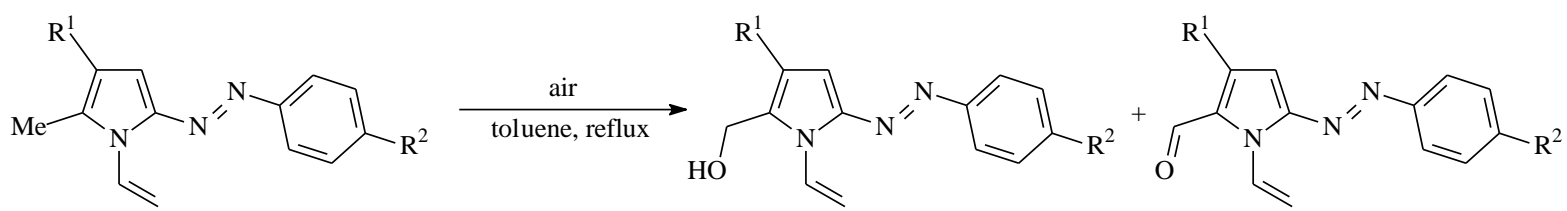

$$
\begin{array}{lll}
\mathbf{1 a} \mathrm{R}^{1}=\mathrm{R}^{2}=\mathrm{H} & \text { 2a } 18 \%\left({ }^{1} \mathrm{H}\right. \text { NMR) } & \text { 3a is not formed } \\
\mathbf{1 b} \mathrm{R}^{1}=\mathrm{Me}, \mathrm{R}^{2}=\mathrm{H} & \mathbf{2 b} 60 \% & \mathbf{3 b} 21 \% \\
\mathbf{1 c} \mathrm{R}^{1}=\mathrm{Me}, \mathrm{R}^{2}=\mathrm{OEt} & \mathbf{2 c} 22 \% & \mathbf{3 c} 9 \% \text { ( } \mathrm{H} \text { NMR) } \\
\mathbf{1 e} \mathrm{R}^{1}=\mathrm{Me}, \mathrm{R}^{2}=\mathrm{NO}_{2} & \text { 2e is not formed } & \text { 3e is not formed }
\end{array}
$$

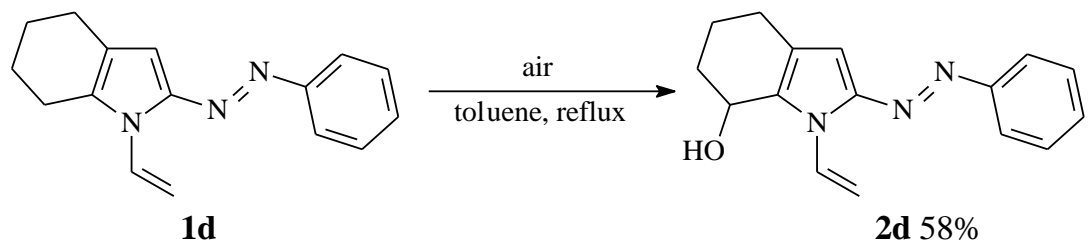

\section{Scheme 1}

The reaction was carried out by refluxing of pyrroles 1a-e in toluene upon passing the air through the reaction mixture for 5-11 h. The oxidation products were isolated by column chromatography. Noteworthy, that when oxygen (instead of air) was employed under the same conditions, the oxidation occurred much faster and no individual products were isolated.

The structure of compounds 2a-d unambiguously follows from the single-crystal X-ray diffraction of compound $\mathbf{2 b}$ as a typical representative of this series (Figure 1) in conjunction with the NMR data (see below). The crystalline structure of pyrrole $\mathbf{2} \mathbf{b}$ is formed by two crystallographically independent molecules $\mathbf{A}$ and $\mathbf{B}$. The conformations of bicyclic parts of both molecules are essentially planar: maximum deviation of atoms out of the averaged plane formed by pyrrole, azo and benzene moieties is $0.10 \AA$ and $0.06 \AA$ for molecules $\mathbf{A}$ and $\mathbf{B}$, respectively. Dihedral angles between the pyrrole plane and that of vinyl group are 151.8 and $146.0^{\circ}$ for molecules $\mathbf{A}$ and $\mathbf{B}$, respectively. Dihedral angles between the pyrrole planes and that of the hydroxyl substituents $\left(\mathrm{C}^{5}-\mathrm{CH}_{2}-\mathrm{O}\right)$ equal to $103.4^{\circ}$ and $101.7^{\circ}$ for molecules $\mathbf{A}$ and $\mathbf{B}$, respectively. The pyrrole and benzene rings are almost coplanar (dihedral angles are $176.4^{\circ}$ and $\left.176.7^{\circ}\right)$. 


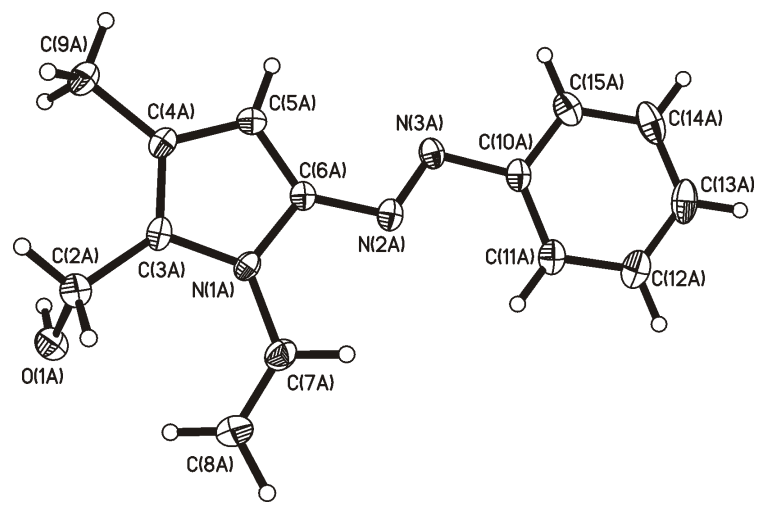

A

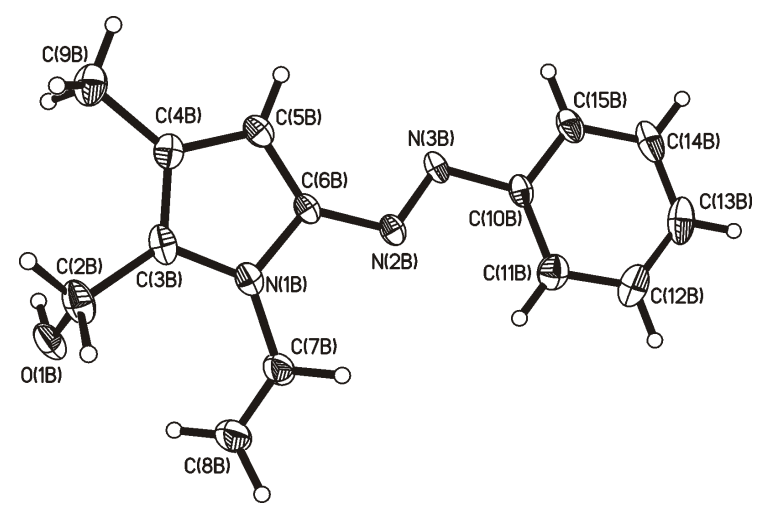

B

Figure 1. ORTEP diagram of $\mathbf{2 b}$.

Molecules of $\mathbf{2 b}$ are associated in pairs by intermolecular H-bonding N(3)...H-O (Figure 2). Contacts and angles between the atoms involved in the H-bonding are $\mathrm{O}(1 \mathrm{~A}) \ldots \mathrm{N}(3 \mathrm{~A})-2.893(3)$ $\AA, \quad \mathrm{H}(1 \mathrm{~A}) \ldots \mathrm{N}(3 \mathrm{~A})-1.97(3) \AA, \mathrm{O}(1 \mathrm{~A})-\mathrm{H}(1 \mathrm{~A})-0.93(3) \AA, \mathrm{O}(1 \mathrm{~A})-\mathrm{H}(1 \mathrm{~A}) \ldots \mathrm{N}(3 \mathrm{~A})-171(3)^{\circ}$, $\mathrm{O}(1 \mathrm{~B}) \ldots \mathrm{N}(3 \mathrm{~B})-2.902(3) \AA, \mathrm{H}(1 \mathrm{~B}) \ldots \mathrm{N}(3 \mathrm{~B})-2.03(3) \AA, \mathrm{H}(1 \mathrm{~B}) \ldots \mathrm{N}(3 \mathrm{~B})-0.87(3) \AA, \mathrm{O}(1 \mathrm{~B})-$ $\mathrm{H}(1 \mathrm{~B}) \ldots \mathrm{N}(3 \mathrm{~B})-176(3)^{\circ}$. The sums of Van-der-Waals radii for $\mathrm{O} . . \mathrm{N}$ and $\mathrm{N} . . . \mathrm{H}$ equal $3.07 \AA$ and $2.75 \AA$, respectively. ${ }^{5}$

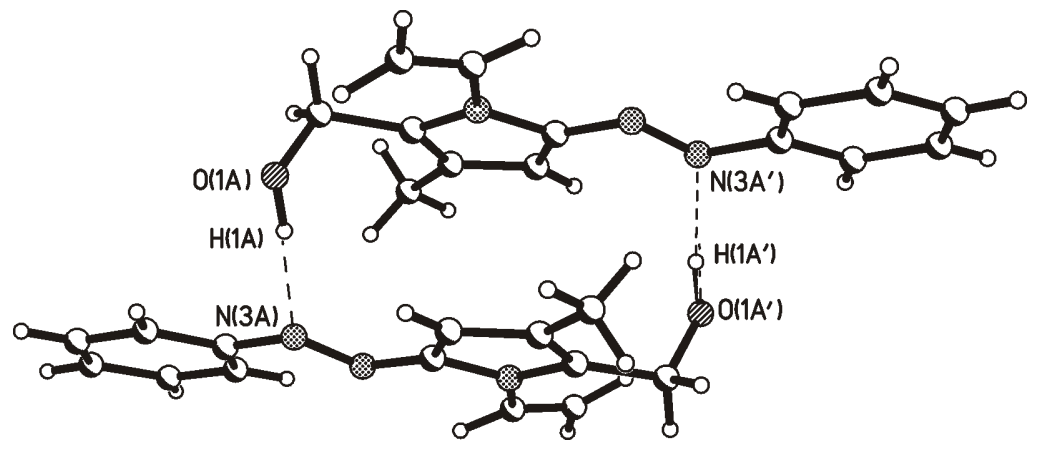

Figure 2. ORTEP diagram of intermolecular H-bonding N(3)...H-O in the crystalline state of molecule $2 \mathbf{b}$.

${ }^{1} \mathrm{H}$ and ${ }^{13} \mathrm{C}$ NMR spectra are in agreement with the X-ray structure of hydroxy derivatives 2a-d. In the ${ }^{1} \mathrm{H}$ NMR spectra of the compounds $\mathbf{2 b - d}$, characteristic are the singlets of the $\mathrm{OH}$ protons (1.64-2.00 ppm), the singlets of the protons of the $5-\mathrm{CH}_{2}$ - for $\mathbf{2 b , \mathbf { c }}(4.68-4.74 \mathrm{ppm})$ or 7 CH-group for $2 \mathbf{d}(4.91 \mathrm{ppm})$ and the signals for the protons of the $\mathrm{N}$-vinyl moiety. In the NOESY spectra of pyrroles $\mathbf{2 b , c}$, cross-peaks of $5-\mathrm{CH}_{2}$ - protons both with 4-Me- and $N$-vinyl protons are detected. Assignments of the ${ }^{13} \mathrm{C}$ signals were based on 2D HSQC and HMBC spectra. 
The structure of aldehydes $\mathbf{3 b}, \mathbf{c}$ was proved by ${ }^{1} \mathrm{H}$ and ${ }^{13} \mathrm{C}$ NMR spectra. For $\mathbf{3 b}$, the singlet at $9.97 \mathrm{ppm}$ in the ${ }^{1} \mathrm{H}$ NMR spectrum together with the ${ }^{13} \mathrm{C}$ resonance at $180.4 \mathrm{ppm}$ are indicative of the formyl function. 2D HSQC and HMBC spectra prove the 5-position of the formyl group.

Apparently, the oxidation of $N$-vinyl-2-phenyldiazenylpyrroles starts with the formation of the hydroperoxide 4 (Scheme 2) which then decomposes to hydroxyl and methoxyl radicals 5. The latter abstract hydrogen atom from the starting pyrrole 1a-c to give the hydroxymethyl derivatives 2a-c and radical $\mathbf{6}$ which recombinates with hydroxyl. Analogically, the oxidation of tetrahydroindole derivative $\mathbf{1 d}$ can be rationalized. There is a probability that the radicals $\mathbf{5}$ and $\mathbf{6}$ are trapped by oxygen from air and not only from hydroxyl radical though in the boiling toluene the partial oxygen pressure should be negligible.

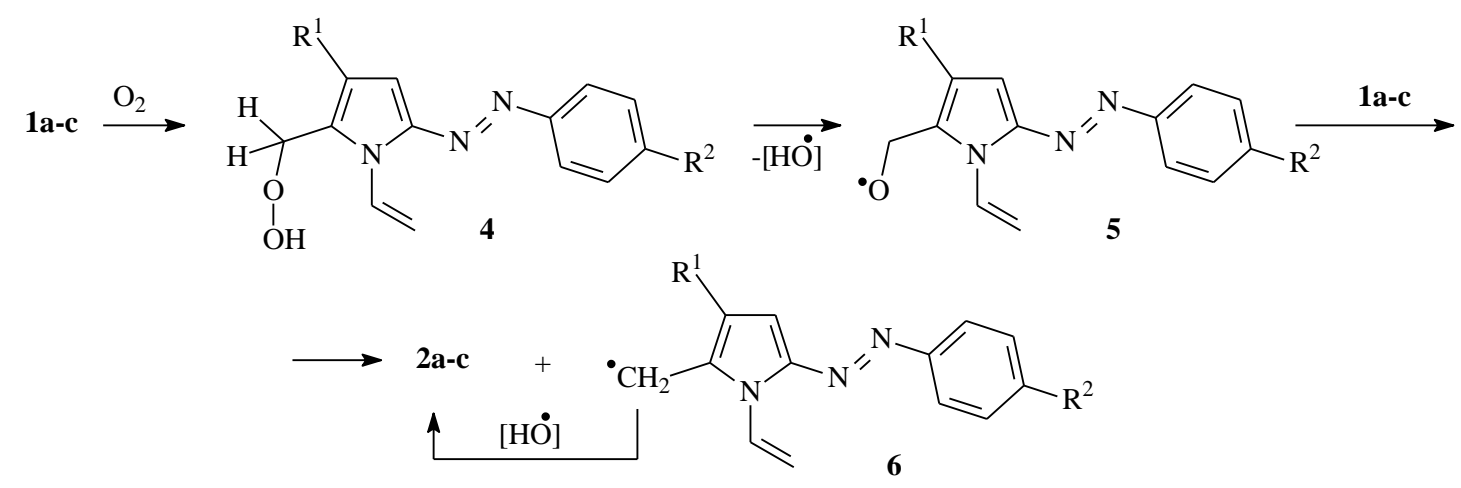

\section{Scheme 2}

The formation of aldehydes $\mathbf{3 b}, \mathbf{c}$ is probably due to the known decomposition of hydroperoxides 4 to release water ${ }^{6}$ (Scheme 3).

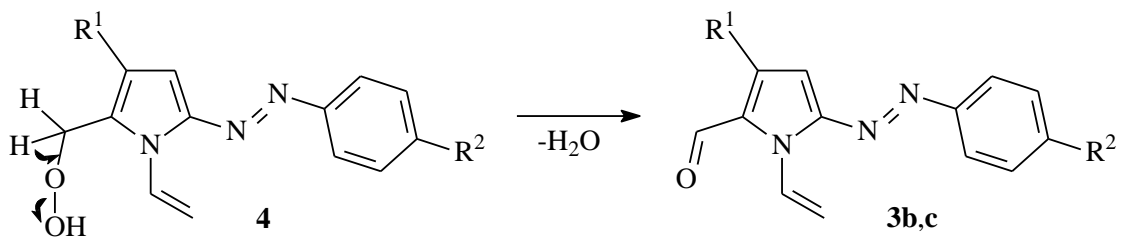

\section{Scheme 3}

The stability of the pyrrole, phenyldiazenyl and $N$-vinyl moieties is likely a result of the electron transfer from the $N$-vinylpyrrole scaffold to the azo group as shown in Scheme $4 .^{3}$ This long-range electron communication along the whole 2-phenyldiazenyl- $N$-vinylpyrrole system is facilitated by the essentially planar structure of these molecules as here is evident from the XRay data (the dihedral angles between $N$-vinyl group and pyrrole plane range $25-34^{\circ}$ only with a very low rotation barrier $^{7}$, Figure 1 ). 


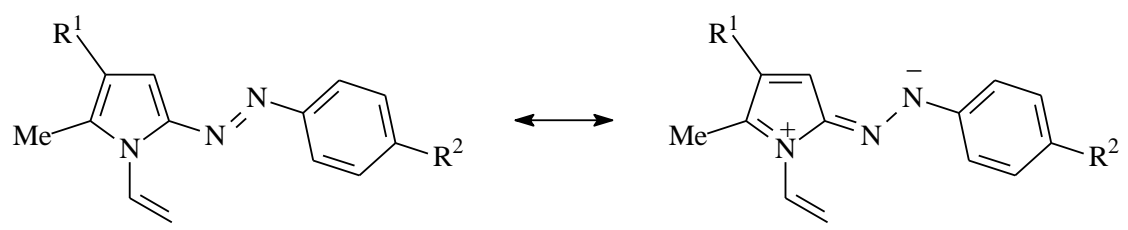

\section{Scheme 4}

Consequently, the susceptibility of the pyrrole ring towards oxidants decreases. Since $N$ vinyl group is in conjugation with the $\pi$-system of the whole molecule ${ }^{8}$, the electron density on the double bond also decreases that explains extraordinary stability of this ethylenic moiety towards the autooxidation.

Notably, that under the same conditions, 2,3-dimethyl- $N$-vinylpyrrole did not undergo the selective oxidation according to Scheme 1, but oxidized deeper to a black tar wherein neither the pyrrole ring nor $N$-vinyl group were detectable $\left({ }^{1} \mathrm{H}\right.$ NMR). This highlights a crucial role of the phenyldiazenyl electron acceptor in the observed unanticipated autooxidation of alkyl substituents in the pyrrole ring.

The substituents effect is in accordance with the above consideration. Actually, an electrondonating substituent in the pyrrole moiety increases, but in the phenyldiazenyl fragment decreases the polarization in the whole conjugation system of the azopyrrole dyes and consequently, the former accelerates and the latter slow down the autooxidation. Stability of $\mathrm{N}$ vinyl group in this system is due to delocalization of electron density of the double bond into the ring and hence the oxidation becomes very slow process. Indeed, when 4-methyl substituent in the pyrrole ring was replaced for less electron-donating hydrogen (pyrrole 1a), the yield of oxidation product $2 \mathrm{a}$ dropped to about $18 \%$ (even after longer reaction time, $38 \mathrm{~h}$ ) compared to $60 \%$ for pyrrole $\mathbf{1 b}(5 \mathrm{~h})$, and no aldehyde $3 \mathbf{a}$ was discernible in the reaction mixture. Respectively, the introduction of ethoxy substituent (a $\pi$-donor) to the para-position of phenyl group (pyrrole 1c) decreased the yield of hydroxy derivative $2 \mathbf{c}$ to $22 \%$ and $9 \%$ of aldehyde $3 \mathbf{c}$ was formed ( ${ }^{1} \mathrm{H}$ NMR). Accordingly, a strong electron-withdrawing substituent $\mathrm{NO}_{2}$ (pyrrole 1e) so deeply polarizes the dye molecule that the addition of water (a product of autooxidation) to the azo group with further rearrangement of the adduct to nitroaniline (43\% yield) occurs (Scheme 5).

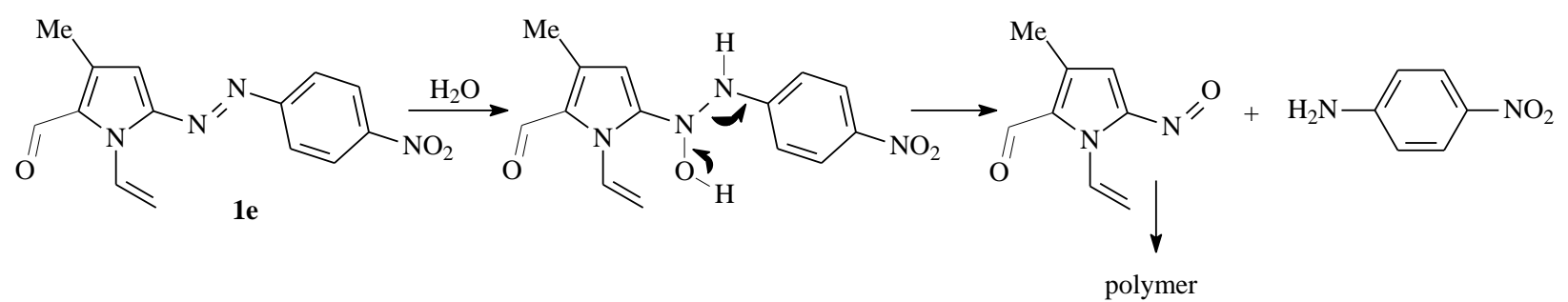

\section{Scheme 5}


The autooxidation reactions are often induced by traces of metals, but here this is not the case because, in parallel with easy oxidation, the robust stabilization of the pyrrole ring takes place that is not common for the pyrrole chemistry.

The facile selective non-catalyzed oxidation of pyrroles 1a-d, if optimized, may be considered as the simplest atom-economic method for functionalization of phenyldiazenylpyrrole dyes.

To summarize, the first examples of easy selective autooxidation of alkyl substituents at the pyrrole moiety of 2-phenyldiazenyl- $N$-vinylpyrrole dyes with retaining the pyrrole moiety intact has been revealed. The reaction contributes to fundamentals of autooxidation of practically important functionalized pyrrole compounds, in particular pyrrole dyes and pigments as well as to the chemistry of heteroalkenes ( $N$-vinyl group) and phenyldiazenyl functions. The results also help to better understand the electron communication within conjugated strongly polarized phenyldiazenylpyrrole structural unit.

\section{Experimental Section}

General. NMR spectra were run on a Bruker DPX 400 spectrometer $\left[400.13\left({ }^{1} \mathrm{H}\right) \mathrm{MHz}, 100.6\right.$ $\mathrm{MHz}\left({ }^{13} \mathrm{C}\right)$ ]; $\mathrm{CDCl}_{3}$ as solvent, HMDS as internal standard. Detailed ${ }^{13} \mathrm{C}$ NMR peak assignments were obtained by careful analysis of HSQC and HMBC 2D NMR spectra. IR spectra were recorded from $\mathrm{KBr}$ pellets on a Bruker IFS-25 instrument. Microanalyses were obtained in the A.E. Favorsky Irkutsk Institute of Chemistry, Siberian Branch of the Russian Academy of Sciences, Russia on an EA FLASH 1112 Series (CHN Analyzer) instrument.

Autooxidation of 4,5-dimethyl-2-phenylazo-1-vinylpyrrole 1b: The pyrrole $\mathbf{1 b}(100 \mathrm{mg},(0.47$ mmol) was refluxed in toluene $(3.5 \mathrm{~mL})$ upon passing the air through the reaction mixture for $5 \mathrm{~h}$. After evaporation of the toluene, the residue $(103 \mathrm{mg})$ was column-chromatographed [basic $\mathrm{Al}_{2} \mathrm{O}_{3}(\mathrm{pH}=8.25)$, hexane - diethyl ether = $\left.3: 1\right)$ to give $58 \mathrm{mg}$ of 5-hydroxymethyl-4-methyl2-phenylazo-1-vinylpyrrole $\mathbf{2 b}(60 \%$ yield, hereinafter based on the starting pyrrole $\mathbf{1 b}$ consumed), $20 \mathrm{mg}$ of 4-methyl-2-phenylazo-1-vinylpyrrol-5-carbaldehyde $\mathbf{3 b}$ (21\% yield) and $10 \mathrm{mg}$ of starting pyrrole $\mathbf{1 b}$ (90\% conversion).

Compounds 2c,d were obtained similarly (reaction time 11 and $5 \mathrm{~h}$ for $\mathbf{2 c}$ and $\mathbf{2 d}$, respectively). In the case of pyrrole 1e (reaction time $5 \mathrm{~h}$ ), only nitroaniline (43\% yield) was isolated after column chromatography. ${ }^{1} \mathrm{H}$ NMR spectra of nitroaniline correspond to the literature data. ${ }^{9}$

5-Hydroxymethyl-4-methyl-2-phenylazo-1-vinylpyrrole 2b: Orange crystals (mp 100-102 $\left.{ }^{\circ} \mathrm{C}\right)$. ${ }^{1} \mathrm{H}$ NMR (400.13 MHz, $\left.\mathrm{CDCl}_{3}\right): \delta 7.78\left(\mathrm{~m}, 2 \mathrm{H}, \mathrm{H}_{o}\right), 7.48\left(\mathrm{dd}, 1 \mathrm{H},{ }^{3} J_{\mathrm{BX}} 16.1 \mathrm{~Hz},{ }^{3} J_{\mathrm{AX}} 9.3 \mathrm{~Hz}, \mathrm{Hx}\right)$, $7.45\left(\mathrm{~m}, 2 \mathrm{H}, \mathrm{H}_{m}\right), 7.36\left(\mathrm{~m}, 1 \mathrm{H}, \mathrm{H}_{p}\right), 6.55(\mathrm{~s}, 1 \mathrm{H}, \mathrm{H} 3), 5.70\left(\mathrm{~d}, 1 \mathrm{H},{ }^{3} J_{\mathrm{BX}} 16.1 \mathrm{~Hz}, \mathrm{H}_{\mathrm{B}}\right), 5.19$ (d, 1H, $\left.{ }^{3} J_{\mathrm{AX}} 9.1 \mathrm{~Hz}, \mathrm{H}_{\mathrm{A}}\right), 4.74$ (s, 2H, $\left.\mathrm{CH}_{2}\right), 2.15$ (s, 3H, Me), 1.64 (br.s, $\left.1 \mathrm{H}, \mathrm{OH}\right) .{ }^{13} \mathrm{C} \mathrm{NMR}(101.61$ $\left.\mathrm{MHz}, \mathrm{CDCl}_{3}\right): \delta 154.1\left(\mathrm{C}_{i}\right), 147.0(\mathrm{C} 2), 132.9(\mathrm{C} 5), 130.2\left(\mathrm{C}_{p}\right), 129.8\left(\mathrm{C}_{\alpha}\right), 129.5\left(\mathrm{C}_{m}\right), 125.7$ $\left(\mathrm{C}_{o}\right), 122.6(\mathrm{C} 4), 108.4\left(\mathrm{C}_{\beta}\right), 100.7(\mathrm{C} 3), 54.7\left(\mathrm{CH}_{2}\right), 11.3(\mathrm{Me}) . \mathrm{IR}(\mathrm{KBr}) v_{\max }: 1639,1596,1501$, 
$1473,1309,1296,1258,1194,1148,1042$, 999, 969, 555. Anal. Calcd for $\mathrm{C}_{14} \mathrm{H}_{15} \mathrm{~N}_{3} \mathrm{O}(241.29)$ : C, 69.69; H, 6.27; N, 17.41. Found: C, 69.86; H, 6.41; N, 17.22.

4-Methyl-2-phenylazo-1-vinylpyrrol-5-carbaldehyde 3b. Orange crystals (from hexane); $\mathrm{mp}$ 90-92 ${ }^{\circ} \mathrm{C} ;{ }^{1} \mathrm{H}$ NMR $\delta 9.97(\mathrm{~s}, 1 \mathrm{H}, \mathrm{HC}=\mathrm{O}), 7.84\left(\mathrm{~m}, 2 \mathrm{H}, \mathrm{H}_{o}\right), 7.74\left(\mathrm{dd},{ }^{3} J_{\mathrm{BX}} 15.7 \mathrm{~Hz},{ }^{3} J_{\mathrm{AX}} 8.9 \mathrm{~Hz}\right.$, $1 \mathrm{H}, \mathrm{Hx}), 7.48\left(\mathrm{~m}, 3 \mathrm{H}, \mathrm{H}_{p}, \mathrm{H}_{m}\right), 6.57$ (s, 1H, H-3), 5.48 (d, $\left.{ }^{3} J_{\mathrm{BX}} 15.7 \mathrm{~Hz}, 1 \mathrm{H}, \mathrm{H}_{\mathrm{B}}\right), 5.40\left(\mathrm{~d},{ }^{3} J_{\mathrm{AX}}\right.$ $\left.8.9 \mathrm{~Hz}, 1 \mathrm{H}, \mathrm{H}_{\mathrm{A}}\right), 2.43(\mathrm{~s}, 3 \mathrm{H}, \mathrm{Me}) ;{ }^{13} \mathrm{C} \mathrm{NMR} \delta 180.4(\mathrm{C}=\mathrm{O}), 153.8\left(\mathrm{C}_{i}\right), 149.5(\mathrm{C}-5), 134.6(\mathrm{C}-4)$, $131.9\left(\mathrm{C}_{p}\right), 129.9\left(\mathrm{C}_{\alpha}\right), 129.8\left(\mathrm{C}_{m}\right), 129.5(\mathrm{C}-2), 123.3\left(\mathrm{C}_{o}\right), 113.5\left(\mathrm{C}_{\beta}\right), 102.4(\mathrm{C}-3), 12.2(\mathrm{Me})$. IR v 3118, 3064, 2953, 2924, 2852, 1704, 1659, 1651, 1598, 1525, 1495, 1481, 1476, 1441, 1428, 1398, 1372, 1335, 1304, 1199, 1154, 1123, 1103, 1072, 1020, 999, 945, 919, 898, 821, 769, 688, 583, 554, 515, 495. Anal. Calcd for $\mathrm{C}_{14} \mathrm{H}_{13} \mathrm{~N}_{3} \mathrm{O}$ (239.28): C, 70.28; H, 5.48; N, 17.56. Found: C, $70.12 ; \mathrm{H}, 5.19 ; \mathrm{N}, 17.38$.

2-(4-Ethoxyphenylazo)-5-hydroxymethyl-4-methyl-1-vinylpyrrole 2c. Yield $22 \%$; orange crystals (from hexane); mp $112-114{ }^{\circ} \mathrm{C} ;{ }^{1} \mathrm{H} \mathrm{NMR} \delta 7.75\left(\mathrm{~d},{ }^{3} J_{o-m} 8.9 \mathrm{~Hz}, 2 \mathrm{H}, \mathrm{H}_{o}\right), 7.45\left(\mathrm{dd},{ }^{3} J_{\mathrm{BX}}\right.$ $16.0 \mathrm{~Hz},{ }^{3} J_{\mathrm{AX}} 9.3 \mathrm{~Hz}, 1 \mathrm{H}, \mathrm{HX}_{\mathrm{X}}, 6.95\left(\mathrm{~d},{ }^{3} J_{o-m} 8.9 \mathrm{~Hz}, 2 \mathrm{H}, \mathrm{H}_{m}\right), 6.45(\mathrm{~s}, 1 \mathrm{H}, \mathrm{H}-3), 5.70\left(\mathrm{~d},{ }^{3} J_{\mathrm{BX}}\right.$ $\left.16.0 \mathrm{~Hz}, 1 \mathrm{H}, \mathrm{H}_{\mathrm{B}}\right), 5.15\left(\mathrm{~d},{ }^{3} J_{\mathrm{AX}} 9.3 \mathrm{~Hz}, 1 \mathrm{H}, \mathrm{H}_{\mathrm{A}}\right), 4.68\left(\mathrm{~s}, 2 \mathrm{H}, \mathrm{CH}_{2}\right), 4.08\left(\mathrm{q},{ }^{3} J_{\mathrm{CH} 2-\mathrm{Me}} 7.0 \mathrm{~Hz}, 2 \mathrm{H}\right.$, $\left.\mathrm{OCH}_{2}\right), 2.12$ (s, 3H, 4-Me), 1.64 (br.s, $\left.1 \mathrm{H}, \mathrm{OH}\right), 1.42$ (s, 3H, $\left.\mathrm{OCH}_{2} \mathrm{Me}\right) ;{ }^{13} \mathrm{C} \mathrm{NMR} \delta 161.5\left(\mathrm{C}_{i}\right)$, $148.7(\mathrm{C}-2), 147.9\left(\mathrm{C}_{p}\right), 132.8(\mathrm{C}-5), 130.3\left(\mathrm{C}_{\alpha}\right), 124.9\left(\mathrm{C}_{m}\right), 122.8(\mathrm{C}-4), 115.7\left(\mathrm{C}_{o}\right), 108.2\left(\mathrm{C}_{\beta}\right)$, $100.6(\mathrm{C}-3), 64.8\left(\mathrm{OCH}_{2}\right), 54.9\left(\underline{\mathrm{CH}}_{2} \mathrm{OH}\right), 15.8$ (4-Me), $12.0\left(\mathrm{CH}_{2} \underline{\mathrm{Me}}\right) ; \mathrm{IR} v 1657,1596,1518$, 1473, 1309, 1296, 1258, 1234, 1194, 1148, 1115, 1042, 999, 969, 848, 556. Anal. Calcd for $\mathrm{C}_{16} \mathrm{H}_{19} \mathrm{~N}_{3} \mathrm{O}_{2}$ (285.35): C, 67.35; H, 6.71; N, 14.73. Found: C, 67.50; H, 6.90; N, 14.55.

7-Hydroxy-2-phenylazo-1-vinyl-4,5,6,7-tetrahydroindole 2d. Yield 58\%; red crystals (from hexane); mp 80-82 ${ }^{\circ} \mathrm{C}$; ${ }^{1} \mathrm{H}$ NMR $\delta 7.77\left(\mathrm{~m}, 2 \mathrm{H}, \mathrm{H}_{o}\right), 7.53\left(\mathrm{dd},{ }^{3} J_{\mathrm{BX}} 16.1 \mathrm{~Hz},{ }^{3} J_{\mathrm{AX}} 9.5 \mathrm{~Hz}, 1 \mathrm{H}, \mathrm{HX}\right)$, $7.46\left(\mathrm{~m}, 2 \mathrm{H}, \mathrm{H}_{m}\right), 7.34\left(\mathrm{~m}, 1 \mathrm{H}, \mathrm{H}_{p}\right), 6.49$ (s, 1H, H-3), $5.78\left(\mathrm{~d},{ }^{3} J_{\mathrm{BX}} 16.1 \mathrm{~Hz}, 1 \mathrm{H}, \mathrm{H}_{\mathrm{B}}\right), 5.08(\mathrm{~d}$, $\left.{ }^{3} J_{\mathrm{AX}} 9.5 \mathrm{~Hz}, 1 \mathrm{H}, \mathrm{H}_{\mathrm{A}}\right), 4.91(\mathrm{~s}, 1 \mathrm{H}, 7-\mathrm{CH}), 2.63 \mathrm{~m}, 2.47 \mathrm{~m}\left(2 \mathrm{H}, 4-\mathrm{CH}_{2}\right), 2.06 \mathrm{~m}, 1.85 \mathrm{~m}(2 \mathrm{H}, 6-$ $\left.\mathrm{CH}_{2}\right), 1,82 \mathrm{~m}, 1,88 \mathrm{~m}\left(2 \mathrm{H}, 5-\mathrm{CH}_{2}\right), 2.00$ (br.s, $\left.1 \mathrm{H}, \mathrm{OH}\right) ;{ }^{13} \mathrm{C} \mathrm{NMR} \delta 153.6\left(\mathrm{C}_{i}\right), 146.9(\mathrm{C}-2)$, $133.5(\mathrm{C}-5), 129.8\left(\mathrm{C}_{p}\right), 129.1\left(\mathrm{C}_{m}\right), 129.0\left(\mathrm{C}_{\alpha}\right), 123.8(\mathrm{C}-4), 122.4\left(\mathrm{C}_{o}\right), 105.8\left(\mathrm{C}_{\beta}\right), 97.9(\mathrm{C}-3)$, 61.3 (C-7), 32.8 (C-6), 23.2 (C-4), 17.8 (C-5). IR v 1642, 1599, 1480, 1450, 1405, 1372, 1296, $1205,1131,1095,1064,1022,987,935,849,812,766,733,710,689,616,577$. Anal. Calcd for $\mathrm{C}_{16} \mathrm{H}_{17} \mathrm{~N}_{3} \mathrm{O}$ (267.33): C, 71.89; H, 6.41; N, 15.72. Found: C, 72.08; H, 6.48; N, 15.63.

\section{Acknowledgements}

This work has been carried out under financial support of leading scientific schools by the President of the Russian Federation (Grant NSH-3230.2010.3) and Russian Foundation for Basic Research (Grant 09-03-00158). 


\section{References and Notes}

1. Jones, R. A.; Bean, G. P. The Chemistry of Pyrroles; Academic Press: London, New York, San Francisco, 1977, p 525. (b) Gossauer A. Die Chemie der Pyrrole, Springer-Verlag: Berlin, Heidelberg, New York, 1974, p 433.

2. Meijer, E. W.; Wynberg, H. Tetrahedron Lett. 1981, 22, 785. (b) Trofimov, B. A.; Lavrov, V. I.; Parshina, L. N.; Ahmedzhanova, Z. A. Russ. J. Org. Chem. 1982, 18, 1994. (c) Parshina, L. N.; Lavrov, V. I.; Trofimov, B. A. Russ. J. Appl. Chem. 1989, 62, 123.

3. Trofimov, B. A.; Schmidt, E. Yu.; Mikhaleva, A. I.; Vasil'tsov, A. M.; Zaitsev, A. B.; Smolyanina, N. S.; Senotrusova, E. Yu.; Afonin, A. V.; Ushakov, I. A.; Petrushenko, K. B.; Kazheva, O. N.; Dyachenko, O. A.; Smirnov, V. V.; Schmidt, A. F.; Markova, M. V.; Morozova, L. V. Eur. J. Org. Chem. 2006, 4021.

4. (a) Chauhan S. M. S., Bisht T., Garg B. Sens. Actuators, B 2009, 141, 116. (b) Li Y., Patrick B. O., Dolphin D. J. Org. Chem. 2009, 74, 5237. (c) Chauhan S. M. S., Garg B., Bisht T. Supramol. Chem. 2009, 21, 394.

5. Bondi, A. J. Phys. Chem. 1964, 68, 441.

6. (a) Harris, E. J. Proc. R. Soc. London, Ser. A 1939, 173, 126. (b) Selvin, R.; Rajarajeswari, G. R.; Roselin, S. L.; Sadasivam, V.; Sivasankar, B.; Rengaraj, K. Appl. Catal., A 2001, 219, 125. (c) Nelson, M. E.; Dykman, A, S.; Zinenkov, A. V.; Pinson, V. V.; Grebenshchikov, I. N. US Patent Application 20090264685, October 22, 2009.

7. Rusakov, Y. Y.; Krivdin, L. B.; Senotrusova, E. Yu.; Schmidt, E. Yu.; Vasil'tsov, A. M.; Mikhaleva, A. I.; Trofimov, B. A.; Dyachenko, O. A.; Chekhlov, A. N.; Kazheva, O. N. Magn. Reson. Chem. 2007, 45, 142.

8. Trofimov, B. A. Vinylpyrroles In: Pyrroles Part Two: The Synthesis, Reactivity, and Physical Properties of Substituted Pyrroles, Ed. Jones, R. A., Wiley: New York, 1992; Vol. 48, p 205.

9. The Merck Index, 12th ed., Entry\# 6681. 